\title{
Mesenchymal/non-epithelial mimickers of neuroendocrine neoplasms with a focus on fusion gene-associated and SWI/SNF-deficient tumors
}

\author{
Atsuko Kasajima ${ }^{1,2}\left(\mathbb{D}^{-}\right.$Björn Konukiewitz ${ }^{3} \cdot$ Anna Melissa Schlitter ${ }^{1,2} \cdot$ Wilko Weichert $^{1,2} \cdot$ Jan Hinrich Bräsen ${ }^{4}$. \\ Abbas Agaimy $^{5}$. Günter Klöppel ${ }^{1}$
}

Received: 27 May 2021 / Revised: 5 July 2021 / Accepted: 7 July 2021 / Published online: 5 August 2021

(c) The Author(s) 2021

\begin{abstract}
Mimickers of neuroendocrine neoplasms (NEN) include a number of important pitfall tumors. Here, we describe our experience with mesenchymal mimics of NENs to illustrate their spectrum and draw the attention particularly to a group of mesenchymal/non-epithelial neoplasms (MN) that combine epithelioid histology with neuroendocrine (NE-) features and peculiar genetic abnormalities. In a consultation series of 4498 cases collected between 2009 and 2021, 2099 neoplasms expressing synaptophysin and/or chromograninA were reviewed and analyzed. A total of 364 (18\%) were diagnosed as non-NENs, while the remaining tumors were NEN. The group of mesenchymal/non-epithelial neoplasms with NE-features (MN-NE) included 31/364 (8\%) cases. These mostly malignant neoplasms showed an epithelioid morphology. While all but one tumor expressed synaptophysin, mostly patchy, only 10/29 (34\%) co-expressed chromograninA. A total of 13/31 (42\%) of the MN-NE showed EWSRl-related gene fusions (6 Ewing sarcomas, 5 clear cell sarcomas, and 1 desmoplastic small round cell tumor, 1 neoplasm with FUS-CREM gene fusion) and 7 (23\%) were SWI/SNF (SMARCB1 or SMARCA4)-deficient neoplasms. The remaining MN-NE included synovial sarcoma, sclerosing epithelioid mesenchymal neoplasm, melanoma, alveolar soft part sarcoma, solitary fibrous tumor, and chordoma. A total of 27/31 MN-NE were from the last 8 years, and 6 of them were located in the pancreas. Eleven MN-NE were initially diagnosed as neuroendocrine carcinomas (NECs). MN-NE with epithelioid features play an increasing role as mimickers of NECs. They mostly belong to tumors with gene fusions involving the EWSRl gene, or with SWI/SNF complex deficiency. Synaptophysin expression is mostly patchy and chromograninA expression is infrequent in MN-NE of this series and data extracted from literature.
\end{abstract}

Keywords Neuroendocrine neoplasms $\cdot$ Mimics $\cdot$ Mesenchymal neoplasms $\cdot$ Genetic features

Atsuko Kasajima

atsuko.kasajima@tum.de

1 Department of Pathology, Technical University Munich, Trogerstr. 18, 81675 Munich, Germany

2 The German Cancer Consortium (DKTK), Heidelberg, Germany

3 Department of Pathology, Universitätsklinikum Schleswig-Holstein, Campus Kiel, Christian-Albrechts-Universität zu Kiel, Kiel, Germany

4 Institute of Pathology, Hannover Medical School, Hannover, Germany

5 Institute of Pathology, Friedrich-Alexander-University, Erlangen-Nürnberg, University Hospital, Erlangen, Germany

\section{Introduction}

Neuroendocrine neoplasms (NENs) originate from various epithelial or neuroectodermal tissues. The NENs are defined by the expression of the neuroendocrine (NE) markers synaptophysin and chromograninA [27, 28]. However, these markers, either alone or both, may also be expressed in neoplasms that are not considered NENs such as complex adenocarcinomas, adrenocortical carcinomas, or sarcomas, which can therefore be confused with NENs.

Analyzing a large number of consultation cases which were received to clarify diagnostic problems in NENs and NEN-like tumors, we defined six groups of tumors and lesions that all expressed synaptophysin, usually together with chromograninA. The first and largest group (true NEN) encompasses all epithelial (cytokeratin positive) and ectodermal (cytokeratin negative) NENs. The second 
group assembles carcinomas with a NE-component (i.e., carcinomas that by definition do not fall into the mixed neuroendocrine non-neuroendocrine neoplasms: MiNEN category) originating from the digestive system, the lung, and the gynecological and urogenital organs and also contains carcinomas of unknown origin. The remaining four groups include acinar cell carcinomas, solid-pseudopapillary neoplasms (SPN), adrenocortical neoplasms, and mesenchymal neoplasms, all of them with NE-features. Many of the collected neoplasms with NE-features have been discussed in the differential diagnosis section of textbooks or review articles and are therefore not presented in detail.

Here, we would like to draw the attention to the group of mesenchymal/non-epithelial neoplasms with NE features, as the group includes more and more NEN-mimickers, which belong to epithelioid mesenchymal tumors with special genetic changes. We collected 31 nonepithelial NEN mimickers and present their morphology, immunohistochemical findings, genetic abnormalities, and diagnostic features.

Since many of these neoplasms do not co-express chromograninA, but only label with synaptophysin, we reviewed the literature to clarify the information about the rate of synaptophysin and chromograninA expression in the various entities of mesenchymal/non-epithelial neoplasms.

\section{Materials and methods}

\section{Tissue assembling}

The Consultation Centre for Pancreatic and Endocrine Neoplasms, Technical University Munich, Germany, received consultation specimens from 4498 patients between April 2009 and April 2021. All cases were reviewed at least by two endocrine and pancreas pathology experts including AK, BK, MS, WW, AA, and GK. In a few cases, the help of tertiary consultation by other expert pathologists was sought (see acknowledgments). We analyzed specimens from 4436 patients and excluded 62 cases because of insufficient materials. In all included cases, slides and/or formalin fixed paraffin embedded (FFPE) tissue blocks were available, containing sufficient material. Cases, in which we received only slides, were included, when all staining needed for final diagnosis were available. When blocks were received, recuts were done for histological and immunohistochemical examination. In some cases, a molecular pathology analysis was added. In 2529/4436 cases (57\%), the final diagnosis required the use of the NE-markers synaptophysin and/or chromograninA (Supplement Fig. 1). Both markers were examined in 1937 neoplasms or lesions, and only one marker in 592 neoplasms or lesions (synaptophysin in 480, chromograninA in 112 cases). The positivity of one marker was regarded as sufficient for the criterion of NE-differentiation
(83\%, 2099/2529). Among 31 mesenchymal neoplasms, 4 cases were also immunostained with INSM1. After excluding 30 non-neoplastic NE-lesions, such as islet cell aggregation or PP-islet accumulations, 2069 cases were diagnosed as NE-marker positive neoplasms. Age, sex, type of specimens, and tissue origins of these patients were extracted from the available documents (see supplemental Table 1). The most frequent tissue origin was the gastrointestinal tract (35\%), followed by pancreatobilliary organs $(20 \%)$ and liver (16\%) (data not shown). The study was approved by our local ethic committee (Internal number: 281/19 s approved on 11.06.2019).

\section{Histopathological and immunohistochemical evaluation}

Hematoxylin and eosin (HE) and periodic acid-Schiff (PAS) staining were done on $2-\mu \mathrm{m}$ thick FFPE tissue sections. Immunohistochemical stainings were performed using a fully automated slide preparation system (Benchmark XT, Ventanta/Roche, AZ, USA). Details regarding the immunohistochemical stainings are given in supplemental Table 2 . Immunohistochemical staining was evaluated according to the percentage of positive cells, and NE-positivity was recorded, when $>5 \%$ of tumor cells stained for at least one of the NE-markers. Furthermore, we distinguished between a diffuse and patchy expression. The expression was called diffuse when all tumor cells were strongly and evenly stained, or was called patchy when the staining of the tumor cells alternates between weak and strongly and the weakly stained cells dominated. In the cases stained with the NE-marker INSM1, weak or strong nuclear staining was regarded positive. Ten pancreatic neuroendocrine tumors (PanNETs) and the islets in the surrounding pancreas served as controls.

\section{Diagnostic criteria of NE-expressing neoplasms}

The diagnosis of the mesenchymal neoplasms with NEfeatures (MN-NE) followed the criteria of the WHO classification [14]. Recent publications were also taken into account, as for instance, in the case of SMARCA4-deficient neoplasms [2], sclerosing epithelial mesenchymal neoplasms (SEMN) [11], or neoplasm with FUS-CREM gene fusion [6, $9,55]$. Molecular testing for the detection of gene fusions was performed using different next generation sequence (NGS) panels, as previously described [5].

Thirty-one MN-NEs were identified and separated from epithelial and ectodermal NENs (including MiNENs [13, 32]) and other groups with NE-features, including carcinomas with a NE-component (i.e., carcinomas that by definition do not fall into the MiNEN category), acinar cell carcinomas (including mixed acinar carcinomas), SPN, and adrenocortical neoplasms. 


\section{Evaluation of the referral diagnoses}

The available suspected or proposed diagnoses of the referrals that concerned MN-NE were compared with the final diagnosis. 24/31 (77\%) of the referrals requested confirmation of the diagnosis and/or subtyping of the tumor. The referral diagnosis was regarded either consistent or inconsistent with the final diagnosis.

\section{Results}

\section{Proportional distribution of MN-NEs among NEN mimickers seen in consultation}

Among 364/2069 (18\%) non-NENs with NE-marker expression, MN-NE $(N=31)$ accounted for $9 \%$. The remaining 333 non-NENs included 139 (38\%) carcinomas, 76 (21\%) acinar cell carcinomas, 25 (7\%) SPNs, and 93 (26\%) adrenocortical neoplasms (Supplemental Fig. 2, supplemental Table 1). A total of 27/31 MN-NEs were observed between 2014 and 2021.

\section{Features of MN-NE}

The $31 \mathrm{MN}-\mathrm{NEs}$ could be assigned to 13 entities. Most frequent were Ewing sarcoma (EWS) and clear cell sarcoma (CCS) of gastrointestinal tract (Table 1 and Supplemental Table 3). Nineteen tumors presented as primaries, 6 of them in the pancreas and 12 as metastases, mostly in the liver (Table 1, Supplemental Tables 1, 3). The tumors shared an epithelioid histology, variably combined with large cell and small round cell, spindle and rhabdoid, morphology (Figs. 1A, 2A, B, 3A) (for details, see Table 1).

All MN-NEs expressed synaptophysin (patchy in 30/31 cases) (Fig. 1C, 2B, 3B), while chromograninA, vimentin, and cytokeratin (Fig. 3C) were only expressed in 11/29 (38\%, patchy $9 / 11$ ), and $15 / 16(94 \%$, patchy $2 / 15)$ and $16 / 24$ (67\%, patchy 8/16) examined cases, respectively (Table 1). Four (including 1 solitary fibrous tumor; SFT, 2 SEMNs and 1 neoplasm with FUS-CREM gene fusion) expressed INSM1.

Ki67 index varied from 1 to $70 \%$ (Fig. 2C). High proliferation ( $>40 \%$ ) was observed in melanoma, epithelioid sarcoma (ES), malignant SFT, and SMARCB1- and SMARCA4-deficient neoplasms. Moderate proliferation (10-40\%) was observed in EWS, CCS, synovial sarcoma (SS), and desmoplastic small round cell tumor (DSRCT) and low proliferation $(<10 \%)$ in chordoma, alveolar soft part sarcoma (ASPS), and SEMN.

Fourteen MN-NEs were diagnosed using the respective immunohistochemical key markers (Table 1, Fig. 1D, 2D, $3 \mathrm{D})$. Seventeen tumors required molecular testing for the detection of gene fusions. This revealed fusions involving the Ewing Sarcoma Breakpoint Region 1 (EWSRI) on $22 \mathrm{q}$ in 12 cases. Together with their immunoprofile, these tumors were diagnosed as EWS (6 cases), CCS (5 cases), and DSRST (one case). Different gene fusions were identified in 5 neoplasms. One case had a FUS-CREM gene fusion $[6,9]$, two cases had SS18- SSX gene fusions characterizing SS, and another two cases had TFE3-ASPSCR1 gene fusions characterizing ASPS (for details, see Table 1).

\section{Comparison of referral opinion/diagnosis and final diagnosis}

Referral and final diagnoses were concordant in only in 2/24 (8\%) cases. Diagnoses regarded as discordant were neuroendocrine carcinoma (NEC, $N=11)$, followed by $\operatorname{NET}(N=3)$ (for details, see Supplemental Table 3). In neoplasms with small round cell morphology, such as EWS or DSRCT, small cell NEC was suggested. In neoplasms with pleomorphic and/or rhabdoid morphology such as SMARCB1-deficient neoplasms, SMARCA4-deficient neoplasms, malignant SFT, and CCS, a diagnosis of large cell NEC was proposed, while a NET diagnosis was discussed in the chordoma case and two of the CCSs.

\section{Discussion}

Mimickers of NEN mainly represent epithelial neoplasms and they are found among various types of adenocarcinomas, acinar cell carcinomas, SPNs, and adrenocortical neoplasms. All these tumors have in common the expression of NE-markers, such as synaptophysin and chromograninA, and an epithelial nature. MN-NEs are rare, but in recent years, we observed an increasing number of these lesions, which often caused considerable diagnostic problems. In this study, we discuss in detail $31 \mathrm{MN}-\mathrm{NEs}$, which accounted for $9 \%$ in a consultation cohort of 364 non-NEN cases (see Supplement Fig. 1).

The MN-NEs, which were spread over 13 entities of sarcomas/mesenchymal neoplasms, shared an epithelioid morphology, with spindle cell, rhabdoid, or small round cell features (Table 1). The precise diagnosis in each case was established by the expression of key immunohistochemical markers, and if needed, by molecular testing (for details, see Table 1). As key NEN markers, we used synaptophysin and chromogranin A, as recommended in the recent WHO classification [27]. Other markers, such as DAXX/ATRX, alternative lengthening of telomeres (ALT), p53, and Rb1, whose abnormal expression or signaling can be helpful in classifying NETs and NECs and determining their prognosis, have not been applied to this series of tumors [25], because they are not helpful in the general distinction 
Table 1 Pathological and molecular characteristics of 31 mesenchymal neoplasms with neuroendocrine features

\begin{tabular}{|c|c|c|c|c|c|c|c|c|c|}
\hline \multirow{2}{*}{$\begin{array}{l}\text { Final diagnosis } \\
\text { Total }\end{array}$} & \multirow{2}{*}{$\begin{array}{l}N(\%) \\
31(100)\end{array}$} & \multirow{2}{*}{$\begin{array}{l}\text { Findings in addition to } \\
\text { epithelioid histology }\end{array}$} & \multicolumn{5}{|c|}{ Positive immunolabeling } & \multirow{2}{*}{$\begin{array}{l}\text { Chromosomal } \\
\text { translocation }\end{array}$} & \multirow[t]{2}{*}{ Fusion gene } \\
\hline & & & Vimentin & CK18 & SYN & $\mathrm{CgA}$ & Other markers & & \\
\hline Ewing sarcoma & $6(19)$ & $\begin{array}{l}\text { Solid-nested, large and } \\
\text { small round cell, cystic }\end{array}$ & $2 / 2$ & $2 / 3$ & $6 / 6$ & $2 / 6$ & CD99, WT1 & $\begin{array}{l}\mathrm{t}(11 ; 22) \\
(\mathrm{q} 24 ; \mathrm{q} 12) \\
\mathrm{t}(11 ; 22) \\
(\mathrm{q} 22 ; \mathrm{q} 12)\end{array}$ & $\begin{array}{l}\text { EWSR1-FLI1 } \\
\text { EWSR1-ERG }\end{array}$ \\
\hline $\begin{array}{l}\text { Clear cell sarcoma } \\
\text { of gastrointestinal } \\
\text { tract }\end{array}$ & $5(16)$ & $\begin{array}{l}\text { Nested, monomorphic, } \\
\text { cystic }\end{array}$ & $2 / 2$ & $0 / 3$ & $5 / 5$ & $2 / 5$ & S100 & $\begin{array}{l}\mathrm{t}(11 ; 22) \\
\quad(\mathrm{q} 13 ; \mathrm{q} 12)\end{array}$ & $\begin{array}{l}\text { EWSR1-ATF1 } \\
\text { EWSR1-CREB }\end{array}$ \\
\hline $\begin{array}{l}\text { Desmoplastic small } \\
\text { round cell tumor }\end{array}$ & $1(3)$ & $\begin{array}{l}\text { Solid, small cell, desmo- } \\
\text { plastic }\end{array}$ & $0 / 1$ & $1 / 1$ & $1 / 1$ & $1 / 1$ & Desmin & $\begin{array}{l}\mathrm{t}(11 ; 22) \\
\quad(\mathrm{p} 13 ; \mathrm{q} 13)\end{array}$ & EWSR1-WT1 \\
\hline $\begin{array}{l}\text { Epithelioid } \\
\text { neoplasm with } \\
\text { FUS-CREM gene } \\
\text { fusion }\end{array}$ & $1(3)$ & $\begin{array}{l}\text { Solid, pseudotubular; } \\
\text { spindelled, eosino- } \\
\text { philic and clear cells }\end{array}$ & $1 / 1$ & $1 / 1$ & $1 / 1$ & $1 / 1$ & MUC1 & $\begin{array}{l}\mathrm{t}(10 ; 16) \\
\quad(\mathrm{p} 11 ; \mathrm{p} 11)\end{array}$ & FUS-CREM ${ }^{a}$ \\
\hline Synovial sarcoma & $2(6)$ & $\begin{array}{l}\text { Solid, pseudotubular; } \\
\text { spindelled, eosino- } \\
\text { philic and clear cells }\end{array}$ & NA & $2 / 2$ & $2 / 2$ & NA & TLE1, EMA & $\begin{array}{l}\mathrm{t}(\mathrm{X} ; 18) \\
\quad(\mathrm{p} 11 ; \mathrm{q} 11)\end{array}$ & SS18-SSX1 \\
\hline $\begin{array}{l}\text { Alveolar soft part } \\
\text { sarcoma }\end{array}$ & $2(6)$ & $\begin{array}{l}\text { Solid, large polygonal } \\
\text { cells, eosinophilic } \\
\text { granular }\end{array}$ & $1 / 1$ & $0 / 2$ & $1 / 2$ & $2 / 2$ & TFE3, Desmin & $\mathrm{t}(2 ; 13)(\mathrm{p} 11 ; \mathrm{q} 25)$ & $\begin{array}{l}\text { ASPSCR1- } \\
\text { TFE3 }\end{array}$ \\
\hline $\begin{array}{l}\text { Solitary fibrous } \\
\text { tumor, malignant }\end{array}$ & $1(3)$ & $\begin{array}{l}\text { Solid, branching vessels, } \\
\text { large and pleomorphic } \\
\text { cells }\end{array}$ & $1 / 1$ & $1 / 1$ & $1 / 1$ & $0 / 1$ & STAT6 & NA & \\
\hline $\begin{array}{l}\text { Epithelioid sar- } \\
\text { coma }\end{array}$ & $1(3)$ & $\begin{array}{l}\text { Solid, large, pleomor- } \\
\text { phic and rhabdoid cells }\end{array}$ & $1 / 1$ & $1 / 1$ & $1 / 1$ & $0 / 1$ & $\begin{array}{l}\text { SMARCB1 } \\
\text { (INI-1) loss }\end{array}$ & NA & \\
\hline $\begin{array}{l}\text { SMARCB1-defi- } \\
\text { cient neoplasm }\end{array}$ & $3(10)$ & $\begin{array}{l}\text { Nested, pseudoglandu- } \\
\text { lar, cystic, rhabdoid }\end{array}$ & $1 / 1$ & $1 / 1$ & $3 / 3$ & $1 / 3$ & $\begin{array}{l}\text { SMARCB1 } \\
\text { (INI-1) loss }\end{array}$ & NA & \\
\hline $\begin{array}{l}\text { SMARCA4 defi- } \\
\text { cient neoplasm }\end{array}$ & $3(10)$ & $\begin{array}{l}\text { Nested, large, pleomor- } \\
\text { phic and clear cells }\end{array}$ & $1 / 1$ & $2 / 2$ & $3 / 3$ & $0 / 3$ & SMARCA4 loss & NA & \\
\hline Melanoma & $3(10)$ & $\begin{array}{l}\text { Solid, spindle, pleomor- } \\
\text { phic }\end{array}$ & $2 / 2$ & $0 / 2$ & $3 / 3$ & $0 / 3$ & $\begin{array}{l}\text { HMB45, } \\
\quad \text { MelanA, S100 }\end{array}$ & NA & \\
\hline $\begin{array}{l}\text { Sclerosing epithe- } \\
\text { lioid mesenchy- } \\
\text { mal neoplasm }\end{array}$ & $2(7)$ & $\begin{array}{l}\text { Nested, large cell, scle- } \\
\text { rosing }\end{array}$ & $2 / 2$ & $2 / 2$ & $2 / 2$ & $2 / 2$ & ERG, CD34 & NA & \\
\hline Chordoma & $1(3)$ & $\begin{array}{l}\text { Nested, monomorphic, } \\
\text { spindle, and clear cells }\end{array}$ & $\mathrm{NA}$ & $0 / 1$ & $1 / 1$ & $0 / 1$ & Brachyury & NA & \\
\hline
\end{tabular}

$C K$ cytokeratin, $S Y N$ synaptophysin, $C g A$ chromogranin A, $N A$ not analyzed

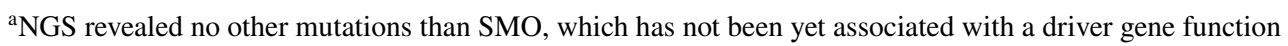

between NENs and non-NENs. In 6 EWSs (three of primary pancreatic origin), 5 CCSs, and one DSRST, we identified gene fusions involving the EWSR1. An involvement of $E W S R I$ gene is probably not a specific event in ME-NEs, since its fusion with BEND2 and FLI1 were detected in 2 cases and 1 case, respectively, of PanNETs in a study of 102 tumors based on whole-genome sequencing [48], suggesting that histological and immunohistochemical determination has an important role in the diagnostic categorization of ME-NEs. Five neoplasms had different gene fusions including a neoplasm with FUS-CREM gene fusion [6, 9], two SS with SS18-SSX gene fusion, two ASPS with TFE3-ASPSCR1 gene fusion, and one SFT with immunolabeling for STAT6 indicating a STAT6-NAB2 gene fusion (for details, see Table 1). Another interesting group encompassing 7 neoplasms were members of the switch/ sucrose non-fermenting (SWI/SNF) complex-deficient group, whose prototype is the ES. The diagnosis of these tumors was based on the immunohistochemical loss of SMARCB1- [1] or SMARCA4 [4, 46] (see Table 1).

Thirty of $31 \mathrm{MN}-\mathrm{NEs}$ were positive for synaptophysin and 11/30 (33\%) cases co-expressed chromograninA. One tumor, an ASPS, expressed only chromograninA. In all the tumors, except two, the expression of both markers was patchy. We also tested selected cases with the new marker INSM1, which is thought to be a crucial regulator of neuroendocrine differentiation [22]. In the four tested cases, 
Fig. 1 Histologic and immunohistochemical images of primary Ewing sarcoma of the pancreas with neuroendocrine features. A Nested cell groups embedded in sclerotic stroma infiltrating pancreatic tissue. B Solid and cystic growth of monomorphic round cells (hematoxylin and eosin staining). Immunohistochemical expression of (C) synaptophysin and (D) CD99

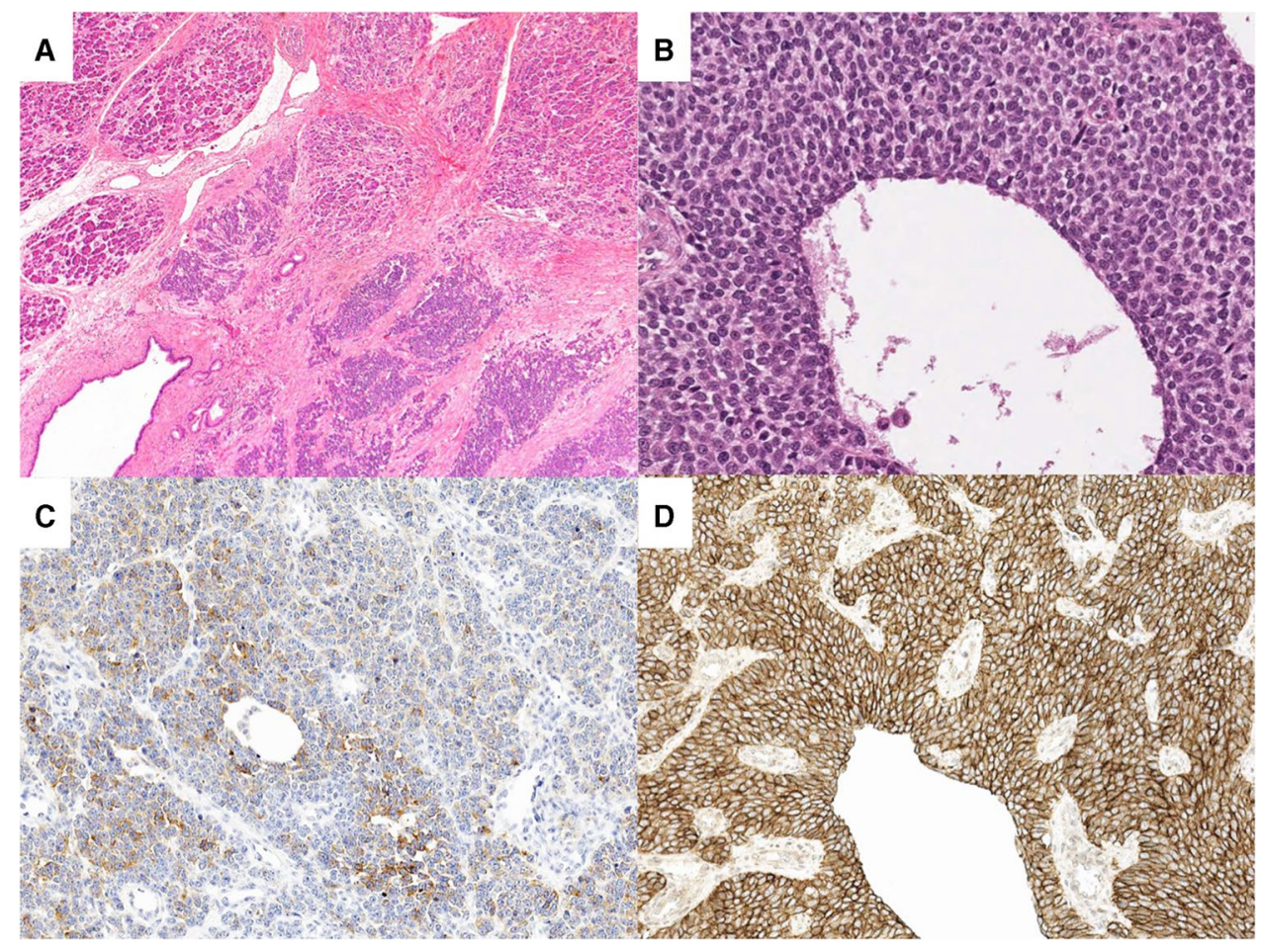

INSM1 labeled many or most nuclei, a pattern that was also observed in PanNETs, which served as controls.

Evaluation of our synaptophysin results with those reported in the literature in sarcomas/mesenchymal neoplasms (see Table 2) showed that synaptophysin is most frequently expressed in CCS [15, 24, 51], DSRCT [38, 41], ES [23], and neoplasms deficient for SMARCB1 [3, 12, 18] and SMARCA4 [2, 4, 44, 46, 54]. In these neoplasms, synaptophysin was recorded in approximately half to two-thirds of the cases, making synaptophysin an important "pitfall
Fig. 2 Histologic and immunohistochemical images of malignant solitary fibrous tumor with neuroendocrine features. A Solid growth composed of middle sized epithelioid cells and containing numerous branching vessels (hematoxylin and eosin staining). Immunohistochemical expression of (B) synaptophysin, (C) Ki67, and (D) STAT6

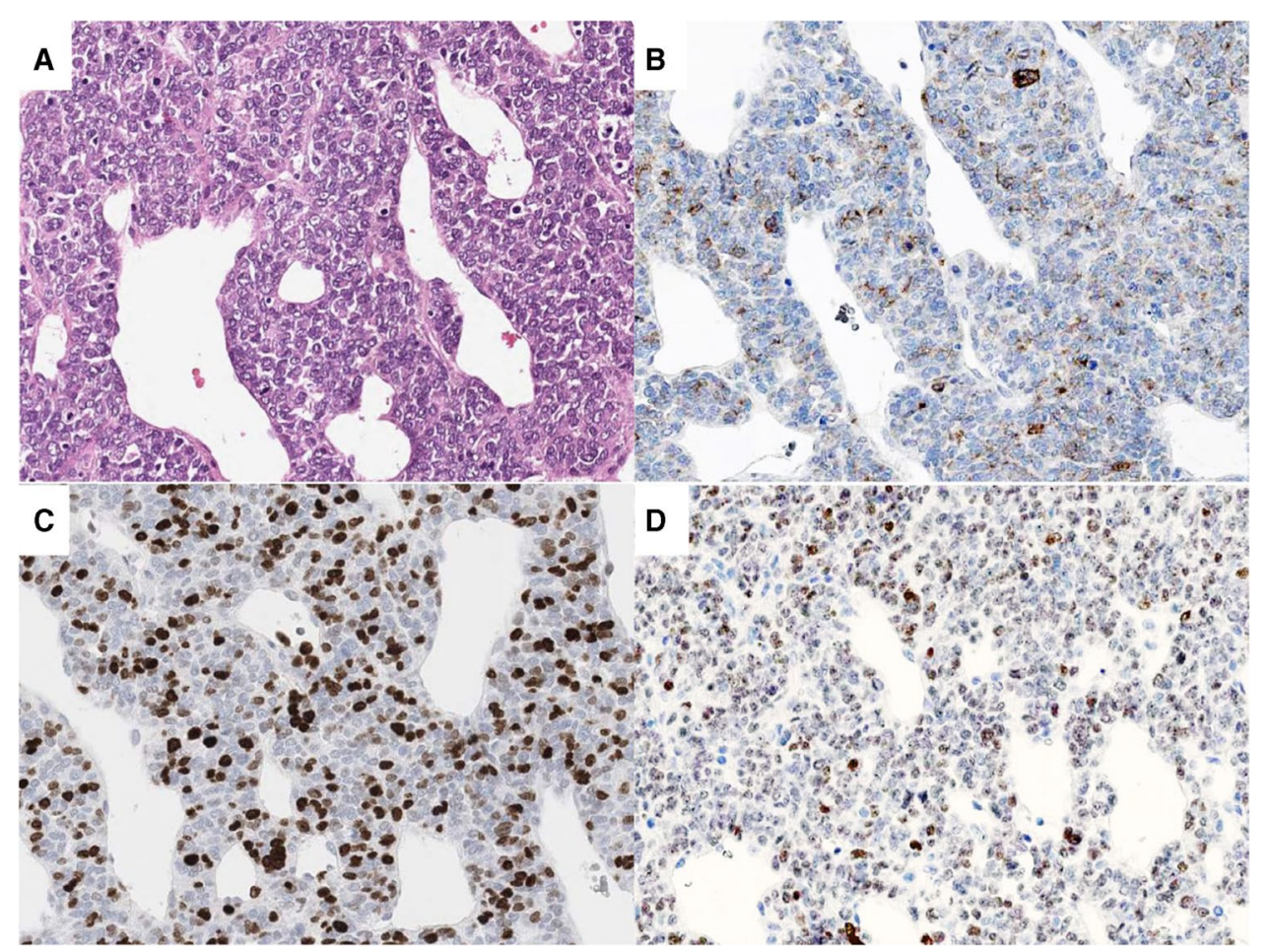


Fig. 3 Histologic and immunohistochemical images of a lymph node metastasis of a SMARCA4-deficient neoplasm. A Solid growth of large pleomorphic cells. Patchy immunohistochemical expression of (B) synaptophysin and (C) cytokeratin 18 and (D) loss of SMARCA4

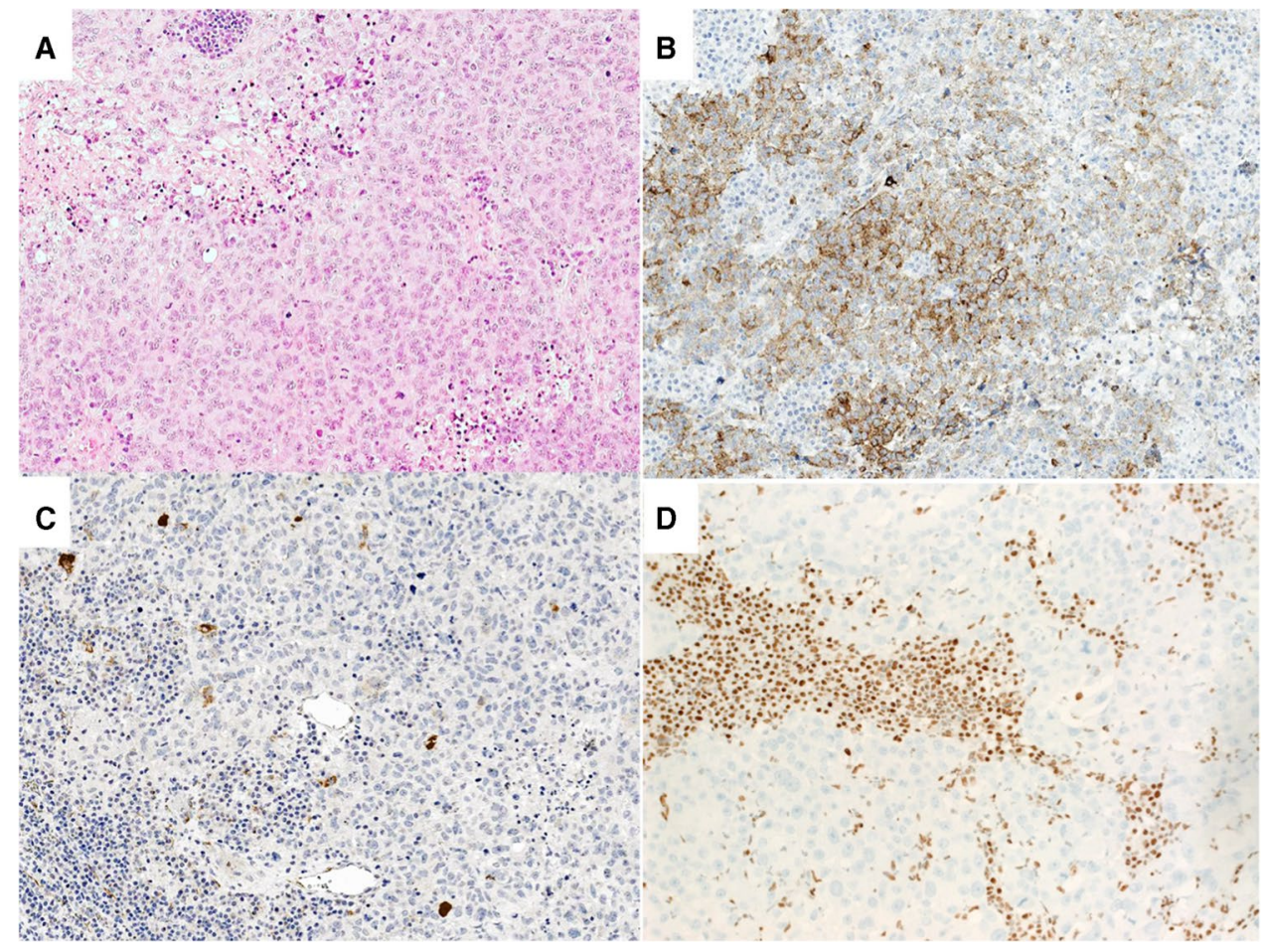

marker" in these neoplasms. Synaptophysin expression was also relatively common in EWS (on average 23\%) [34, 40, 45] and melanoma (on average 35\%) [47, 50], while in SFT [19, 30, 33], chordoma [39], and the pancreatic SEMN [11], synaptophysin expression seems to be rare. A new finding is the synaptophysin positivity in one of our two ASPS [16, $17,20,21,26,36,53]$ and the epithelioid mesenchymal neoplasm with FUS-CREM gene fusion [6, 9, 35]. In contrast to the other MN-NEs with their patchy staining, synaptophysin (as well as chromograninA) labeled the FUS-CREM neoplasm diffusely [6].

Regarding the chromograninA labeling, our data as well as the data from literature revealed a striking dichotomy of synaptophysin and chromograninA expression. Synaptophysin-chromograninA co-expression was observed in $34 \%$ of our MN-NEs and in 5/92 (5\%) neoplasms from the literature $[2-4,12,15,18,19,23,30,33,34,36,38-42$, 44, 46, 47, 49, 50, 54] (see Table 1 and 2), suggesting that the dichotomy in the synaptophysin-chromograninA expression is a common finding in these neoplasms and contrasts sharply with the expression rates in PanNETs, in which chromograninA labels $91 \%$ of the synaptophysin positive tumors [52]. Among our chromograninA, negative MN-NEs were SFT, ES, SMARCA4-deficient neoplasm, melanoma, and chordoma. The literature review confirms SFT, ES, melanoma, and chordoma as tumors in which chromograninA is not or only rarely found, and adds CCS, SS, ASS, and SEMN to this list. This list can be further expanded by the adrenocortical neoplasms [31] and pancreatic SPNs [29], which are other examples of NEN mimickers characterized by chromograninA negativity in the presence of synaptophysin. The reason for the sole expression of synaptophysin is not clear, since both, synaptophysin and chromograninA, appear to be involved in the NE program that is governed by the NE-differentiation regulator INSM1, a transcription factor regulated by the Notch1-Hes1 signaling pathway [22]. However, the fact that chromogranin A, as a protein which is an integral part of the neurosecretory (hormone) granule membrane, is probably only expressed when secretory granules are formed, suggests that the formation of secretory granules as a sign of complete NE-differentiation of a cell is lost earlier than the production of synaptophysin which is a constituent of synaptic-like vesicles, the function of which is not known in NE-cells but might be a more basic NEdifferentiation component. In the light of these considerations, the sole expression of chromograninA, as seen in one of our two ASS and in two cases in Table 2, is difficult to understand, but might be due to a kind of protein mimicry which gives rise to unspecific immunolabeling.

Probably due to their extreme rarity, our series includes no cases of gastrointestinal glomus tumors, which were frequently found to express synaptophysin but not chromogranin A [37]. We also did not observe any alveolar rhabdomyosarcoma, which may express synaptophysin and chromograninA [10]. The recently described GLI1altered (GLI1-rearranged or amplified) malignant epithelioid soft tissue neoplasms that may show a striking 
Table 2 Neuroendocrine expression in mesenchymal neoplasms reported in previous studies

\begin{tabular}{|c|c|c|c|c|c|}
\hline \multirow[t]{2}{*}{ Entitiy } & \multirow[t]{2}{*}{ SYN } & \multirow[t]{2}{*}{$\mathrm{CgA}$} & \multicolumn{2}{|l|}{ Co-expression } & \multirow[t]{3}{*}{ Location } \\
\hline & & & All cases & $\mathrm{CgA} / \mathrm{SYN}$ & \\
\hline & \multicolumn{4}{|c|}{$\%$ (number positive/examined) } & \\
\hline \multirow[t]{3}{*}{ Clear cell sarcoma of gastrointestinal tract $24,15,51$} & $44(14 / 32)$ & NA & NA & NA & Soft tissue \\
\hline & $41(7 / 17)$ & $0(0 / 15)$ & $0(0 / 15)$ & $0 / 7$ & Gastrointestinal tract \\
\hline & $56(9 / 16)$ & NA & NA & NA & Gastrointestinal tract \\
\hline \multirow[t]{3}{*}{ Ewing sarcoma $40,45,34$} & $15(4 / 27)$ & $0(0 / 27)$ & $0(0 / 27)$ & $0 / 4$ & unspecified \\
\hline & $25(4 / 16)$ & NA & NA & NA & Mostly soft tissue \\
\hline & $8(5 / 14)$ & $8(1 / 12)^{*}$ & $0(0 / 11)$ & $0 / 3$ & Pancreas \\
\hline \multirow[t]{2}{*}{ Desmoplastic small round cell tumor ${ }^{41,38}$} & $16(3 / 19)$ & $5(1 / 22)$ & Unspecified & NA & unspecified \\
\hline & $100(6 / 6)$ & $25(1 / 4)^{*}$ & $0(0 / 4)$ & $0 / 0$ & Mostly abdominal cavity \\
\hline \multirow[t]{2}{*}{ Synovial sarcoma 40,49} & $0(0 / 23)$ & $0(0 / 23)$ & $0(0 / 23)$ & $0 / 0$ & unspecified \\
\hline & $50(1 / 2)$ & $0(0 / 2)$ & $0(0 / 2)$ & $0 / 1$ & Soft tissue/retroperitoneum \\
\hline \multirow[t]{2}{*}{ Alveolar soft part sarcoma $36,53,26,16,16,31,20$} & $0(0 / 7)$ & NA & NA & NA & Soft tissue \\
\hline & $0(0 / 5)$ & $0(0 / 4)$ & $0(0 / 4)$ & $0 / 0$ & $\begin{array}{l}\text { Case reports: soft tissue, head } \\
\text { and neck, prostate, mediasti- } \\
\text { num }\end{array}$ \\
\hline \multirow[t]{3}{*}{ Solitary fibrous tumor ${ }^{30,33,19}$} & $17(4 / 23)$ & $0(0 / 23)$ & $0(0 / 23)$ & $0 / 4$ & Central nerve system \\
\hline & $0(0 / 28)$ & $0(0 / 28)$ & $0(0 / 28)$ & $0 / 0$ & Mostly extrapleural soft tissue \\
\hline & $0(0 / 13)$ & $0(0 / 13)$ & $0(0 / 13)$ & $0 / 0$ & Pleura \\
\hline Epithelioid sarcoma ${ }^{23}$ & $60(12 / 20)$ & $0(0 / 20)$ & $0(0 / 20)$ & $0 / 12$ & Soft tissue \\
\hline \multirow[t]{3}{*}{ SMARCB1 deficient neoplasm $18,12,3$} & $66(12 / 18)$ & $0(0 / 18)$ & $0(0 / 18)$ & $0 / 12$ & Soft tissue \\
\hline & $63(5 / 8)$ & $0(0 / 9)$ & $0(0 / 8)$ & $0 / 5$ & Sinonasal tract \\
\hline & $18(6 / 33)$ & $10(3 / 30)$ & $4(1 / 26)^{* *}$ & $1 / 6$ & Sinonasal tract \\
\hline \multirow[t]{5}{*}{ SMARCA4 deficient neoplasm $4,46,44,54,1$} & $90(9 / 10)$ & $40(4 / 10)$ & $40(4 / 10)^{* * *}$ & $4 / 9$ & Sinonasal tract \\
\hline & $73(16 / 22)$ & NA & NA & NA & Thoracic cavity \\
\hline & $18(3 / 17)$ & $0(0 / 17)$ & $0(0 / 17)$ & $0 / 3$ & Thoracic cavity \\
\hline & $25(1 / 4)$ & $0(0 / 3)$ & not specified & $0 / 1$ & Thoracic cavity \\
\hline & $12(2 / 16)$ & $0(0 / 16)$ & $0(0 / 16)$ & $0 / 2$ & Lung \\
\hline \multirow[t]{2}{*}{ Melanoma ${ }^{50,47}$} & $45(9 / 19)$ & $0(0 / 19)$ & $0(0 / 19)$ & $0 / 9$ & Mostly metastasis \\
\hline & $29(10 / 34)$ & $0(0 / 32)$ & $0(0 / 32)$ & $0 / 10$ & Mostly metastasis \\
\hline Sclerosing epithelioid mesenchymal neoplasm ${ }^{11}$ & $13(1 / 8)$ & $0(0 / 8)$ & $0(0 / 8)$ & $0 / 1$ & Pancreas \\
\hline Chordoma ${ }^{39}$ & $9(3 / 33)$ & $0(0 / 32)$ & $0(0 / 32)$ & $0 / 3$ & Mostly lumbosacral \\
\hline Total & $32(155 / 490)$ & $2(7 / 387)$ & $1(5 / 356)$ & $5(5 / 92)$ & \\
\hline
\end{tabular}

Abbreviation: $S Y N$ synaptophysin, $C g A$ chromograninA, $N A$ not analyzed

* ChromograninA expression only in 1 case

*** Focal expression of both markers

*** 3 cases with focal expression of both markers, one case with diffuse synaptophysin and focal chromogranin expression

neuroendocrine-like structure were not observed in our consultation series $[7,8,43]$.

In 11/ 31 MN-NEs, the referral diagnosis was NECs, probably not only because they were synaptophysin and chromograninA positive, but also because some of them presented as pancreatic primaries (see Table 1). To distinguish between MN-NEs and NECs, it is important to observe the heterogeneous histology of MN-NEs in combination with the patchy expression of synaptophysin and the absent or patchy chromograninA labeling. In our MN-NEs, epithelioid cells were often mixed with spindled, small, pleomorphic, rhabdoid, or clear cells. In addition, occasionally, the epithelioid cells formed focal pseudotrabecular/pseudoglandular structures. Finally, some MN-NEs such as DSRCT, SEMN [11], and chordoma displayed a conspicuous stromal component. Such a mixture of heterologous elements is rare or absent in NECs. The other feature of MN-NEs, the patchy expression of synaptophysin and the absence or focality of chromograninA staining, are also rare in NECs, and particularly in NETs, which instead show a diffuse and usually intense staining. The complete absence of chromograninA should always arouse suspicion against the diagnosis of 
Fig. 4 Diagnostic algorithm of tumors with neoplasms with epithelioid-mesenchymal morphology and expression of synaptophysin and/or chromograninA. Footnote: Abbreviations: NET neuroendocrine tumor, NEC neuroendocrine carcinoma, PG garaganglioma, $\mathrm{PC}$ pheochromocytoma, NB neuroblastoma, ACC acinar cell carcinoma, MiNEN mixed neuroendocrine nonneuroendocrine neoplasm, SPN solidpseudopapillary neoplasm, ACN adrenocortical neoplasm, SYN synaptophysin, CgA chromograninA, SF1 seteroid factor 1

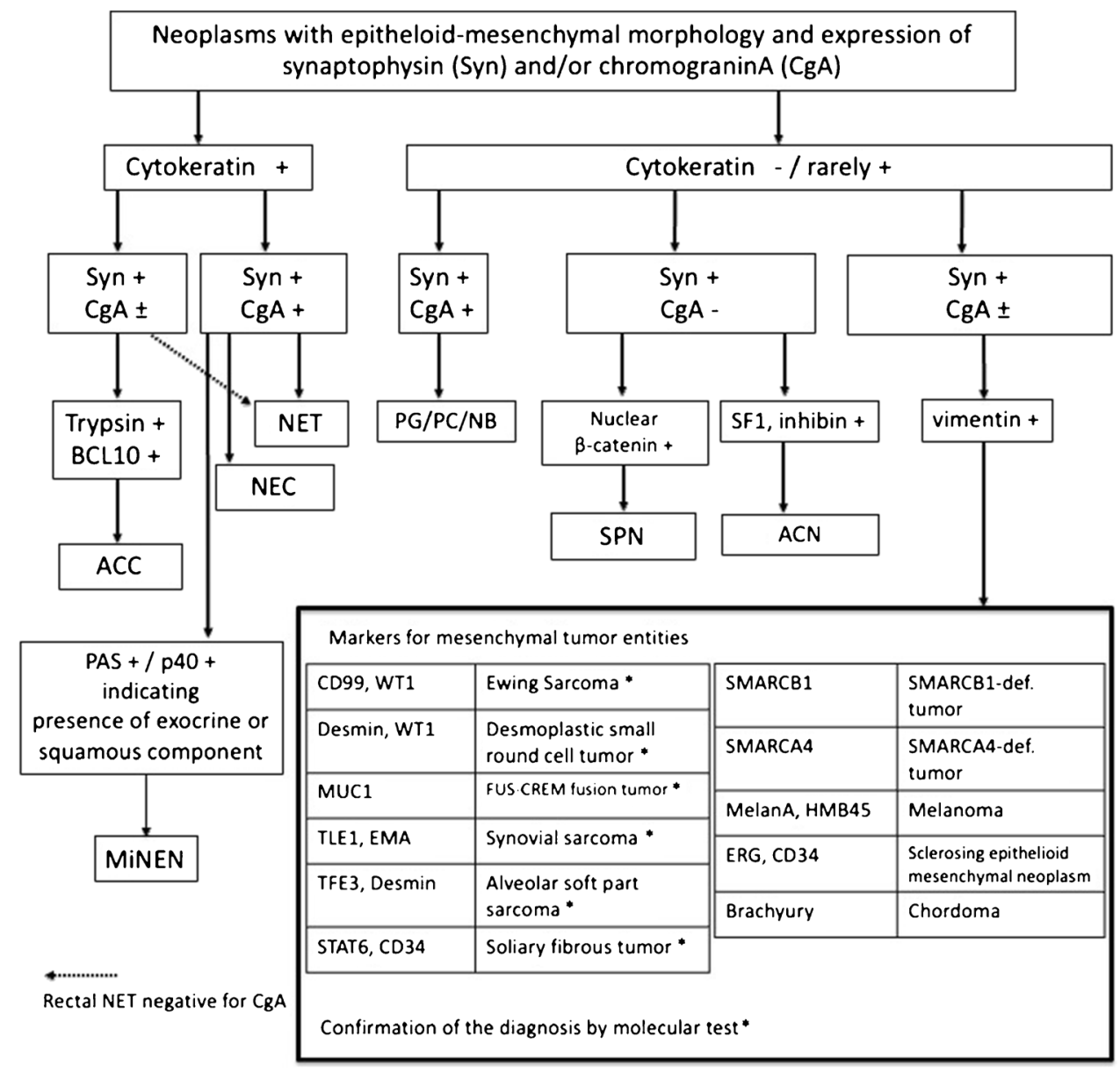

$\mathrm{NEC/NET,} \mathrm{as} \mathrm{was} \mathrm{seen} \mathrm{in} \mathrm{the} \mathrm{chordoma} \mathrm{case,} \mathrm{which} \mathrm{ran}$ for years under the diagnosis of a metastasized NET based on a positive synaptophysin staining only, never accompanied by any chromograninA labeling. In cases of doubtful synaptophysin staining, the new NE-marker INSM1 could help clarify NE-differentiation [52]. Finally, NECs and especially NETs are diffusely cytokeratin 18-positive and usually vimentin-negative, while in MN-NE positivity for vimentin is stronger than that for cytokeratin.

In conclusion, MN-NEs represent only a small group among the various NEN mimickers, but have been increasingly noticed in recent years and are particularly found among new entities of mesenchymal tumors that share an epithelioid-mesenchymal morphology, show a variegated immunophenotype, are characterized by gene fusion alterations in the $C R E B$ family or mutations of SMARC genes, and can occur as pancreatic primaries. All these tumors may cause diagnostic problems in the distinction from NECs and to a minor degree also NETs. However, careful analysis of morphology and immunophenotype in combination with a molecular examination usually reveals the right diagnosis (Fig. 4). The genetic mechanisms that cause and underlie the production of synaptophysin or chromograninA in
non-NENs are so far not understood, but it seems that synaptophysin or synaptophysin-like proteins are more commonly produced in cells of non-NEN than chromograninA.

Supplementary Information The online version contains supplementary material available at https://doi.org/10.1007/s00428-021-03156-9.

Acknowledgements The authors would like to thank all pathologists, who submitted cases for consultation and thus made this work possible.

Special thanks for collaboration are given to Prof. Christopher D.M. Fletcher, Surgical Pathology, Brigham, and Women's Hospital, Boston, USA, Prof. Thomas Mentzel, Dermatopathology, Friedrichshafen, Germany, Prof. Dr. Jürgen Schlegel, Neuropathology, Technical University Munich, and Dr. Gratiana Hermann, Assaf HaRofeh Medical Center, Tel Aviv, Israel. The authors would like to acknowledge Ms. Petra Meyer and the staff of the molecular pathology laboratory (Department of Pathology, Technical University Munich, Germany) for excellent technical support.

Author contribution AK and GK: design of the study, acquisition, analysis and interpretation of data, drafting the manuscript. AA: interpretation of data, revising the manuscript critically for important intellectual content and scientific integrity. BK, AMS, WW, JHB: reading and revising the manuscript critically for important intellectual content and scientific integrity. All authors have read and approved the final manuscript. 
Funding Open Access funding enabled and organized by Projekt DEAL. Manfred-Stolte Research Funding provided financial support to this work.

\section{Declarations}

Ethics approval The study was approved by our local ethic committee (Internal number: 281/19 s approved on 11.06.2019).

Conflict of interest The authors declare no competing interests.

Open Access This article is licensed under a Creative Commons Attribution 4.0 International License, which permits use, sharing, adaptation, distribution and reproduction in any medium or format, as long as you give appropriate credit to the original author(s) and the source, provide a link to the Creative Commons licence, and indicate if changes were made. The images or other third party material in this article are included in the article's Creative Commons licence, unless indicated otherwise in a credit line to the material. If material is not included in the article's Creative Commons licence and your intended use is not permitted by statutory regulation or exceeds the permitted use, you will need to obtain permission directly from the copyright holder. To view a copy of this licence, visit http://creativecommons.org/licenses/by/4.0/.

\section{References}

1. Agaimy A, Haller F, Frohnauer J, Schaefer IM, Strobel P, Hartmann A, Stoehr R, Kloppel G (2015) Pancreatic undifferentiated rhabdoid carcinoma: KRAS alterations and SMARCB1 expression status define two subtypes. Mod Pathol 28:248-260. https:// doi.org/10.1038/modpathol.2014.100

2. Agaimy A, Fuchs F, Moskalev EA, Sirbu H, Hartmann A, Haller F (2017) SMARCA4-deficient pulmonary adenocarcinoma: clinicopathological, immunohistochemical, and molecular characteristics of a novel aggressive neoplasm with a consistent TTF1(neg)/ CK7(pos)/HepPar-1(pos) immunophenotype. Virchows Arch 471:599-609. https://doi.org/10.1007/s00428-017-2148-5

3. Agaimy A, Hartmann A, Antonescu CR, Chiosea SI, El-Mofty SK, Geddert H, Iro H, Lewis JS Jr, Markl B, Mills SE, Riener MO, Robertson T, Sandison A, Semrau S, Simpson RH, Stelow E, Westra WH, Bishop JA (2017) SMARCB1 (INI-1)-deficient sinonasal carcinoma: a series of 39 cases expanding the morphologic and clinicopathologic spectrum of a recently described entity. Am J Surg Pathol 41:458-471. https://doi.org/10.1097/ PAS.0000000000000797

4. Agaimy A, Jain D, Uddin N, Rooper LM, Bishop JA (2020) SMARCA4-deficient sinonasal carcinoma: a series of 10 cases expanding the genetic spectrum of SWI/SNF-driven sinonasal malignancies. Am J Surg Pathol 44:703-710. https://doi.org/10. 1097/PAS.0000000000001428

5. Agaimy A, Togel L, Haller F, Zenk J, Hornung J, Markl B (2020) YAP1-NUTM1 gene fusion in porocarcinoma of the external auditory canal. Head Neck Pathol 14:982-990. https://doi.org/ 10.1007/s12105-020-01173-9

6. Agaimy A, Stöhr R, Otto M, Bräsen J, Pfarr N, Konukiewitz B, Kasajima A, Hartmann A, Klöppel G (2021) Intra-abdominal EWSR1/FUS-CREM-rearranged malignant epithelioid neoplasms: two cases of an emerging aggressive entity with emphasis on misleading immunophenotype. Virchows Arch. https://doi.org/ 10.1007/s00428-021-03140-3

7. Agaram NP, Zhang L, Sung YS, Singer S, Stevens T, PrietoGranada CN, Bishop JA, Wood BA, Swanson D, Dickson BC,
Antonescu CR (2019) GLI1-amplifications expand the spectrum of soft tissue neoplasms defined by GLI1 gene fusions. Mod Pathol 32:1617-1626. https://doi.org/10.1038/s41379-019-0293-x

8. Antonescu CR, Agaram NP, Sung YS, Zhang L, Swanson D, Dickson BC (2018) A distinct malignant epithelioid neoplasm with GLI1 gene rearrangements, frequent S100 protein expression, and metastatic potential: expanding the spectrum of pathologic entities with ACTB/MALAT1/PTCH1-GLI1 fusions. Am J Surg Pathol 42:553-560. https://doi.org/10.1097/PAS.0000000000001010

9. Argani P, Harvey I, Nielsen GP, Takano A, Suurmeijer AJH, Voltaggio L, Zhang L, Sung YS, Stenzinger A, Mechtersheimer G, Dickson BC, Antonescu CR (2020) EWSR1/FUS-CREB fusions define a distinctive malignant epithelioid neoplasm with predilection for mesothelial-lined cavities. Mod Pathol 33:2233-2243. https://doi.org/10.1038/s41379-020-0646-5

10. Bahrami A, Gown AM, Baird GS, Hicks MJ, Folpe AL (2008) Aberrant expression of epithelial and neuroendocrine markers in alveolar rhabdomyosarcoma: a potentially serious diagnostic pitfall. Mod Pathol 21:795-806. https://doi.org/10.1038/modpathol. 2008.86

11. Basturk O, Weigelt B, Adsay V, Benhamida JK, Askan G, Wang L, Arcila ME, Zamboni G, Fukushima N, Gularte-Merida R, Da Cruz PA, Selenica P, Kumar R, Pareja F, Maher CA, Scholes J, Oda Y, Santini D, Doyle LA, Petersen I, Flucke U, Koelsche C, Reynolds SJ, Yavas A, Deimling AV, Reis-Filho JS, Klimstra DS (2020) Sclerosing epithelioid mesenchymal neoplasm of the pancreas - a proposed new entity. Mod Pathol 33:456-467. https:// doi.org/10.1038/s41379-019-0334-5

12. Bishop JA, Antonescu CR, Westra WH (2014) SMARCB1 (INI1)-deficient carcinomas of the sinonasal tract. Am J Surg Pathol 38:1282-1289. https://doi.org/10.1097/PAS.0000000000000285

13. Board WCoTE (2019) WHO Classification of Tumours. Digestive System Tumours. International Agency for Research on Cancer (IARC). Lyon

14. Board WcoTE (2020) WHO classification of tumours: soft tissue and bone tumours. International Agency for Research on Cancer (IARC). Lyon

15. Chang B, Yu L, Guo WW, Sheng WQ, Wang L, Lao I, Huang D, Bai QM, Wang J (2020) Malignant gastrointestinal neuroectodermal tumor: clinicopathologic, immunohistochemical, and molecular analysis of 19 cases. Am J Surg Pathol 44:456-466. https://doi.org/10.1097/PAS.0000000000001396

16. Coupland SE, Heimann H, Hoffmeister B, Lee WR, Foerster MH, Gross U (1999) Immunohistochemical examination of an orbital alveolar soft part sarcoma. Graefes Arch Clin Exp Ophthalmol 237:266-272. https://doi.org/10.1007/s004170050231

17. do Nascimento Souza KC, Faria PR, Costa IM, Duriguetto AF Jr, Loyola AM (2005) Oral alveolar soft-part sarcoma: review of literature and case report with immunohistochemistry study for prognostic markers. Oral Surg Oral Med Oral Pathol Oral Radiol Endod 99:64-70. https://doi.org/10.1016/j.tripleo.2004.07.002

18. Fanburg-Smith JC, Hengge M, Hengge UR, Smith JS Jr, Miettinen M (1998) Extrarenal rhabdoid tumors of soft tissue: a clinicopathologic and immunohistochemical study of 18 cases. Ann Diagn Pathol 2:351-362. https://doi.org/10.1016/s1092-9134(98) 80038-5

19. Fattahi Masuom SH, Bagheri R, Sadrizadeh A, Nouri Dalouee M, Taherian A, Rajaie Z (2016) Outcome of surgery in patients with solitary fibrous tumors of the pleura. Asian Cardiovasc Thorac Ann 24:18-22. https://doi.org/10.1177/0218492315614977

20. Flieder DB, Moran CA, Suster S (1997) Primary alveolar soft-part sarcoma of the mediastinum: a clinicopathological and immunohistochemical study of two cases. Histopathology 31:469-473. https://doi.org/10.1046/j.1365-2559.1997.2690871.x 
21. Folpe AL, Deyrup AT (2006) Alveolar soft-part sarcoma: a review and update. J Clin Pathol 59:1127-1132. https://doi.org/10.1136/ jcp.2005.031120

22. Fujino K, Motooka Y, Hassan WA, Ali Abdalla MO, Sato Y, Kudoh S, Hasegawa K, Niimori-Kita K, Kobayashi H, Kubota I, Wakimoto J, Suzuki M, Ito T (2015) Insulinoma-associated protein 1 is a crucial regulator of neuroendocrine differentiation in lung cancer. Am J Pathol 185:3164-3177. https://doi.org/10. 1016/j.ajpath.2015.08.018

23. Hasegawa T, Matsuno Y, Shimoda T, Umeda T, Yokoyama R, Hirohashi S (2001) Proximal-type epithelioid sarcoma: a clinicopathologic study of 20 cases. Mod Pathol 14:655-663. https://doi. org/10.1038/modpathol.3880368

24. Hisaoka M, Ishida T, Kuo TT, Matsuyama A, Imamura T, Nishida K, Kuroda H, Inayama Y, Oshiro H, Kobayashi H, Nakajima T, Fukuda T, Ae K, Hashimoto H (2008) Clear cell sarcoma of soft tissue: a clinicopathologic, immunohistochemical, and molecular analysis of 33 cases. Am J Surg Pathol 32:452-460. https://doi.org/10.1097/PAS.0b013e31814b18fb

25. Kasajima A, Konukiewitz B, Oka N, Suzuki H, Sakurada A, Okada Y, Kameya T, Ishikawa Y, Sasano H, Weichert W, Klöppel G (2019) Clinicopathological profiling of lung carcinoids with a Ki67 index > 20. Neuroendocrinology 108:109-120. https://doi.org/10.1159/000495806

26. Khanna P, Paidas CN, Gilbert-Barness E (2008) Alveolar soft part sarcoma: clinical, histopathological, molecular, and ultrastructural aspects. Fetal Pediatr Pathol 27:31-40. https://doi.org/ $10.1080 / 15513810802026526$

27. Klimstra D, Klöppel G, La Rosa Salas B, Rindi G (2019) Classification of neuroendocrine neoplasms of the digestive system. In: The WHO Classification of Tumours Editorial Board (ed) WHO Classification of Tumours. Digestive System Tumours, 5th edn. IARC Press, Lyon, pp 16-21

28. Klöppel G, Couvelard A, Hruban R, Klimstra D, Komminoth P, Osamura RY, Perren A, Rindi G (2017) Neuroendocrine neoplasms of the pancreas. In: Lloyd RV, Osamura RY, Klöppel G, Rosai J (ed) WHO classification of Tumours of Endocrine Organs, 4th edn. IARC Press, Lyon, pp 210-239

29. La Rosa S, Bongiovanni M (2020) Pancreatic solid pseudopapillary neoplasm: key pathologic and genetic features. Arch Pathol Lab Med 144(7):829-837. https://doi.org/10.5858/arpa. 2019-0473-RA

30. Liang Y, Heller RS, Wu JK, Heilman CB, Tischler AS, Arkun K (2019) High p16 expression is associated with malignancy and shorter disease-free survival time in solitary fibrous tumor/hemangiopericytoma. J Neurol Surg B Skull Base 80:232-238. https:// doi.org/10.1055/s-0038-1669419

31. Lloyd RV (2011) Adrenal cortical tumors, pheochromocytomas and paragangliomas. Mod Pathol 24(Suppl 2):S58-65. https://doi. org/10.1038/modpathol.2010.126

32. Lloyd RV, Osamura RY, Klöppel G, Rosai J (2017) WHO Classification of Tumours of Endocrine Organs. Lyon: International Agency for Research on Cancer (IARC)

33. Machado I, Morales GN, Cruz J, Lavernia J, Giner F, Navarro S, Ferrandez A, Llombart-Bosch A (2020) Solitary fibrous tumor: a case series identifying pathological adverse factors-implications for risk stratification and classification. Virchows Arch 476:597607. https://doi.org/10.1007/s00428-019-02660-3

34. Mao Y, Sang X, Liang N, Yang H, Lu X, Yang Z, Du S, Xu Y, Zhao H, Zhong S, Huang J, Millis JM (2013) Peripheral primitive neuroectodermal tumors arising in the pancreas: the first case report in Asia and a review of the 14 total reported cases in the world. Hepatobiliary Surg Nutr 2:51-60. https://doi.org/10.3978/j. issn.2304-3881.2012.08.01

35. Memon RA, Granada CNP, Patel C, Manne U, Heslin MJ, Gbolahan OB, Harada S, Diffalha SA (2020) Gastric sclerosing epithelioid fibrosarcoma harboring a rare FUS-CREM fusion. Int J Surg Pathol 29(5):565-570. https://doi.org/10.1177/1066896920 961174

36. Miettinen M, Ekfors T (1990) Alveolar soft part sarcoma Immunohistochemical evidence for muscle cell differentiation. Am J Clin Pathol 93:32-38. https://doi.org/10.1093/ajcp/93.1.32

37. Miettinen M, Paal E, Lasota J, Sobin LH (2002) Gastrointestinal glomus tumors: a clinicopathologic, immunohistochemical, and molecular genetic study of 32 cases. Am J Surg Pathol 26:301311. https://doi.org/10.1097/00000478-200203000-00003

38. Mohamed M, Gonzalez D, Fritchie KJ, Swansbury J, Wren D, Benson C, Jones RL, Fisher C, Thway K (2017) Desmoplastic small round cell tumor: evaluation of reverse transcription-polymerase chain reaction and fluorescence in situ hybridization as ancillary molecular diagnostic techniques. Virchows Arch 471:631-640. https://doi.org/10.1007/s00428-017-2207-y

39. O'Hara BJ, Paetau A, Miettinen M (1998) Keratin subsets and monoclonal antibody HBME-1 in chordoma: immunohistochemical differential diagnosis between tumors simulating chordoma. Hum Pathol 29:119-126. https://doi.org/10.1016/s0046-8177(98) 90220-9

40. Olsen SH, Thomas DG, Lucas DR (2006) Cluster analysis of immunohistochemical profiles in synovial sarcoma, malignant peripheral nerve sheath tumor, and Ewing sarcoma. Mod Pathol 19:659-668. https://doi.org/10.1038/modpathol.3800569

41. Ordonez NG (1998) Desmoplastic small round cell tumor: II: an ultrastructural and immunohistochemical study with emphasis on new immunohistochemical markers. Am J Surg Pathol 22:1314 1327. https://doi.org/10.1097/00000478-199811000-00002

42. Pagani A, Macri L, Rosolen A, Toffolatti L, Stella A, Bussolati G (1998) Neuroendocrine differentiation in Ewing's sarcomas and primitive neuroectodermal tumors revealed by reverse transcriptase-polymerase chain reaction of chromogranin mRNA Diagnostic. Mol Pathol 7:36-43. https://doi.org/10.1097/00019 606-199802000-00007

43. Papke DJ Jr, Dickson BC, Sholl L, Fletcher CDM (2021) Pseudoendocrine sarcoma: clinicopathologic analysis of 23 cases of a distinctive soft tissue neoplasm with metastatic potential, recurrent CTNNB1 mutations, and a predilection for truncal locations. Am J Surg Pathol. https://doi.org/10.1097/PAS.0000000000 001751

44. Perret R, Chalabreysse L, Watson S, Serre I, Garcia S, Forest F, Yvorel V, Pissaloux D, Thomas de Montpreville V, Masliah-Planchon J, Lantuejoul S, Brevet M, Blay JY, Coindre JM, Tirode F, Le Loarer F (2019) SMARCA4-deficient thoracic sarcomas: clinicopathologic study of 30 cases with an emphasis on their nosology and differential diagnoses. Am J Surg Pathol 43:455-465. https:// doi.org/10.1097/PAS.0000000000001188

45. Rekhi B, Shetty O, Vora T, Gulia A, Bajpai J, Laskar S (2020) Clinicopathologic, immunohistochemical, molecular cytogenetic profile with treatment and outcomes of 34 cases of Ewing sarcoma with epithelial differentiation, including 6 cases with "Adamantinoma-like" features, diagnosed at a single institution. India Ann Diagn Pathol 49:151625. https://doi.org/10.1016/j.anndiagpath. 2020.151625

46. Rekhtman N, Montecalvo J, Chang JC, Alex D, Ptashkin RN, Ai N, Sauter JL, Kezlarian B, Jungbluth A, Desmeules P, Beras A, Bishop JA, Plodkowski AJ, Gounder MM, Schoenfeld AJ, Namakydoust A, Li BT, Rudin CM, Riely GJ, Jones DR, Ladanyi M, Travis WD (2020) SMARCA4-deficient thoracic sarcomatoid tumors represent primarily smoking-related undifferentiated carcinomas rather than primary thoracic sarcomas. J Thorac Oncol 15:231-247. https://doi.org/10.1016/j.jtho.2019.10.023

47. Romano RC, Carter JM, Folpe AL (2015) Aberrant intermediate filament and synaptophysin expression is a frequent event in 
malignant melanoma: an immunohistochemical study of 73 cases. Mod Pathol 28:1033-1042

48. Scarpa A, Chang DK, Nones K, Corbo V, Patch AM, Bailey P, Lawlor RT, Johns AL, Miller DK, Mafficini A, Rusev B, Scardoni M, Antonello D, Barbi S, Sikora KO, Cingarlini S, Vicentini C, McKay S, Quinn MC, Bruxner TJ, Christ AN, Harliwong I, Idrisoglu S, McLean S, Nourse C, Nourbakhsh E, Wilson PJ, Anderson MJ, Fink JL, Newell F, Waddell N, Holmes O, Kazakoff SH, Leonard C, Wood S, Xu Q, Nagaraj SH, Amato E, Dalai I, Bersani S, Cataldo I, Dei Tos AP, Capelli P, Davi MV, Landoni L, Malpaga A, Miotto M, Whitehall VL, Leggett BA, Harris JL, Harris J, Jones MD, Humphris J, Chantrill LA, Chin V, Nagrial AM, Pajic M, Scarlett CJ, Pinho A, Rooman I, Toon C, Wu J, Pinese M, Cowley M, Barbour A, Mawson A, Humphrey ES, Colvin EK, Chou A, Lovell JA, Jamieson NB, Duthie F, Gingras MC, Fisher WE, Dagg RA, Lau LM, Lee M, Pickett HA, Reddel RR, Samra JS, Kench JG, Merrett ND, Epari K, Nguyen NQ, Zeps N, Falconi M, Simbolo M, Butturini G, Van Buren G, Partelli S, Fassan M, Australian Pancreatic Cancer Genome I, FKhanna KK, Gill AJ, Wheeler DA, Gibbs RA, Musgrove EA, Bassi C, Tortora G, Pederzoli P, Pearson JV, Waddell N, Biankin AV, Grimmond SM (2017) Whole-genome landscape of pancreatic neuroendocrine tumours. Nature 543:65-71. https://doi.org/10.1038/nature21063

49. Setsu N, Kohashi K, Endo M, Yamamoto H, Ohishi Y, Sueyoshi K, Iwamoto Y, Tsuneyoshi M, Motoi T, Kumagai A, Oda Y (2012) Inhibin-alpha and synaptophysin immunoreactivity in synovial sarcoma with granular cell features. Hum Pathol 43:850-857. https://doi.org/10.1016/j.humpath.2011.07.012

50. Steppert C, Krugmann J, Sterlacci W (2020) Simultaneous endocrine expression and loss of melanoma markers in malignant melanoma metastases, a retrospective analysis. Pathol Oncol Res 26:1777-1779. https://doi.org/10.1007/s12253-019-00761-7

51. Stockman DL, Miettinen M, Suster S, Spagnolo D, DominguezMalagon H, Hornick JL, Adsay V, Chou PM, Amanuel B, Vantuinen P, Zambrano EV (2012) Malignant gastrointestinal neuroectodermal tumor: clinicopathologic, immunohistochemical, ultrastructural, and molecular analysis of 16 cases with a reappraisal of clear cell sarcoma-like tumors of the gastrointestinal tract. Am J Surg Pathol 36:857-868. https://doi.org/10.1097/PAS. 0b013e31824644ac

52. Tanigawa M, Nakayama M, Taira T, Hattori S, Mihara Y, Kondo R, Kusano H, Nakamura K, Abe Y, Ishida Y, Okabe Y, Hisaka T, Okuda K, Fujino K, Ito T, Kawahara A, Naito Y, Yamaguchi R, Akiba J, Akagi Y, Yano H (2018) Insulinoma-associated protein 1 (INSM1) is a useful marker for pancreatic neuroendocrine tumor. Med Mol Morphol 51:32-40. https://doi.org/10.1007/ s00795-017-0167-6

53. Wang JR, Rao Q, Li H, Wang YH, Sun Y, Si HP, Shen LS, Liu CY, Zhang YF (2018) Alveolar soft-part sarcoma of the prostate: a case report and review of the literature. Int J Clin Exp Pathol 11:5126-5132

54. Yoshida A, Kobayashi E, Kubo T, Kodaira M, Motoi T, Motoi N, Yonemori K, Ohe Y, Watanabe SI, Kawai A, Kohno T, Kishimoto H, Ichikawa H, Hiraoka N (2017) Clinicopathological and molecular characterization of SMARCA4-deficient thoracic sarcomas with comparison to potentially related entities. Mod Pathol 30:797-809. https://doi.org/10.1038/modpathol.2017.11

55. Yoshida A, Wakai S, Ryo E, Miyata K, Miyazawa M, Yoshida KI, Motoi T, Ogawa C, Iwata S, Kobayashi E, Watanabe SI, Kawai A, Mori T (2019) Expanding the phenotypic spectrum of mesenchymal tumors harboring the EWSR1-CREM fusion. Am J Surg Pathol 43:1622-1630. https://doi.org/10.1097/PAS.0000000000 001331

Publisher's note Springer Nature remains neutral with regard to jurisdictional claims in published maps and institutional affiliations. 